\title{
Albanon
}

Revistë kulturore

\section{Pasqyrimi i themelimit të Normales së Elbasanit në shtypin kombëtar}

\section{(në 110-vjetorin e fillimit të punës së saj)}

Hajrullah KOLIQI

Njëqind e dhjetë vjet më parë, më 1 dhjetor 1909, filloi veprimtarinë e saj Normalja e Elbasanit, "tempulli i ditunisë kombëtare", siç e cilësoi drejtori i parë i saj, Luigj Gurakuqi. Themelimi i Normales shënon një ngjarje të madhe dhe pikë referimi në historinë e arsimit dhe të shkollës kombëtare shqipe. Ajo ishte shkolla e parë e mesme profesionale, pedagogjike shqipe në gjeografinë shqiptare. Ishte shkollë kombëtare, jo vetëm nga forma dhe përmbajtja, por edhe për faktin se nxënësit, mësimdhënësit dhe veprimtarët e saj ishin nga vise të ndryshme të Shqipërisë etnike dhe nga ngulimet e diasporës shqiptare. Ishte institucion iluminist me të cilin u bashkua dhe identifikua një komb i tërë. Normalen e Elbasanit, Luigj Gurakuqi fillimisht e përkufizoi si "shkollë të madhe për mësonjës". Zyrtarisht u quajt Shkolla Normale e Elbasanit, u mbiquajt "Normalja eXhuvanit" (për nder të drejtorit, ideatorit dhe profesorit shumëvjeçar të saj, Aleksandër Xhuvanit), ndërsa studiuesit e mëvonshëm, duke iu referuar kontekstit historik, funksionit dhe rëndësisë së saj për arsimin e shqiptar, atë e cilësuan "akademi pedagogjike", përkatësisht "universiteti i parë shqiptar".

Përpjekjet për themelimin e Normales së Elbasanit, si dhe për konsolidimin e veprimtarisë së saj, para dhe gjatë vitit të parë shkollor (1909/10), u pasqyruan gjerësisht edhe në organet e shtypit kombëtar të kohës, siç ishin: "Tomorri" (Elbasan), "Bachkim' i Kombit" (Manastir), "Bashkimi" (Shkodër), "Korça” (Korçë), "Shkupi” (Shkup), "Liria” (Selanik), "Rrufeja” (Egjypt), "Flamuri" (Boston) etj. Veprimtarinë e Normales ato e përcollën në mënyrë të vazhdueshme, pothuaj të përditëshme. Për më tepër, organet e 
shtypit kombëtar ishin edhe një nga levat kryesore dhe shumë të rëndësishme të themelimit dhe aktivitetit të saj.

Vizioni dhe misioni i Normales, sipas shtypit kombëtar. Normalja e Elbasanit ishte institucion kulmor i Rilindjes Kombëtare, i cili filloi të marrë jetë me vendimin e parë të Kongresit Arsimor të Elbasanit (2-8 IX 1909). Vendimet e tij u publikuan në të gjitha organet e shtypit kombëtar në fillim të shek. XX. Në gazetën "Bachkim' i Kombit" nr. 1/ 1909, ndër të tjera, lexojmë: "Të fillohet dhe të niset këtë vjeshtë ndë Elbasan një mësonjëtore për mësonjës në gjashtë rieshta për të përmbajturit e së cilës janë detyruarë tërë kllubet dhe shoqëritë brënda dhe jashtë Shqipërisë sikundrë dhe tërë njerëzit që dëshirojnë përparimin e kombit Shqipëtar."

Plan-programi mësimor i kësaj shkolle, sipas gazetës "Bachkimi'i Kombit" nr. 6/1909, do të jetë "sipas shkollave të huaja të këtij qëllimi, kështu që nxënësi që mbaron këtë shkollë për veç që do të ketë një arsim të sosur do të jetë dhe mësonjës me diplomë për shkollat e para dhe të dyta." Organet e shtypit kombëtar njoftojnë se drejtori i Normales Luigj Gurakuqi, në ceremoninë e përurimit të saj, ndër të tjera theksoi: "Me këtë shkollë të madhe për mësonjës, që ishte dëshiri e shpresa e të parëvet t’anë prej vjetësh, fillesën e së cilës na jemi mbledhunë sot të kremtojmë bashkarisht, kombi shqyptar po mbiell farën $e$ dituniës, po heth themelin e mësimit, pse nga kjo shkollë do të dalin ata apostuj të nxehtë e të vullnetshmë që do të përhapin dritën ndër ato ma terrtat vise; do të dalin ato burra njeridashësë, të cilët si Orfeu e si Amfioni, me urtësiën e me ambëlsiën e fjalëvet e të këshillevet të veta do të zbutin egërsinat, do të tundin currat e shkambijt, do të qytetërojnë e t’afrojnë njerëzit e t’i bajnë që të duhen e të ndihmohen si vëllau me vëllanë!...”(“Normalisti”, numër përkujtimor 19091959).

Për realizimin e këtij misioni të madh kombëtar, Kongresi i Elbasanit vendosi që gjuhë mësimi në këtë shkollë të ishte gjuha shqipe (e folmja e Elbasanit) dhe ajo të themelohej në Elbasan, i cili në shtypin e kohës cilësohej si "kërthiza" e Shqipërisë apo "qytet fort i përmendun në t'bukren historii t’onë, e në t'cillin deri tash vonë giuha arbënore asht kenë rueitun gjithmonë maa e kulluet n'gojë t’atyne gjytetasve,..." ("Bashkimi” nr. 3/1909). Edhe në gazetën "Korça” nr. 11/1909, ndër të tjera lexojmë: "Istorija do ti shkruanje me shkronja të arta emërat e atyre të bekuar priftrinj të cilët patnë fatnë të mësojnë dhe t’i luten Zotit, për të parën herë në Shqipëri, në gjuhën e bukur shqipe... ”. Ndër argumenta të shumtë për themelimin e kësaj shkolle në Elbasan, që theksoheshin në shtypin e kohës, veçojmë edhe njoftimin se z. Peter Dotbiba dhe dy patriotë të tjerë elbasanas "paten mendimin e bukur qi t’u ngjisin femivet të tyne emna 


\section{Albanon}

Revistë kulturore

thjesht Shqipe. Kështu pra kemi në Elbasan tri goca me emna Aférdita, Bukuria, Liria" ("Korça" nr. 24/ 1909).

Normalen e themeloi dhe e mbajti vetë populli shqiptar. Kongresi i Elbasanit u mor edhe me jetësimin e vendimit për themelimin e Normales së Elbasanit, duke përfshirë këtu edhe sigurimin e bazës materiale-financiare të veprimtarisë së saj. Nga shtypi mësojmë se grumbullimi i mjeteve financiare filloi gjatë punimeve të Kongresit, ku kontribuan drejtpërdrejt pjesëmarrësit e tij, drejtues klubesh e shoqërish kombëtare dhe individë të veçantë. Gjithashtu, Kongresi “votoj 700 lira për motin e parë...” ("Bachkim' i Kombit"nr.10/1909). Për sigurimin e kushteve materiale-financiare të Shkollës Normale, por edhe të shkollave të tjera shqipe, Kongresi i Elbasanit vendosi që të themelojë Shoqërinë e Mësonjëtoreve Shqip "Përparim", me seli në Korçë. Për këtë qëllim, siç njoftohet në shtyp, Kongresi zgjodhi edhe një komision prej "10 zotërinjëve: Midhat Frashëri, Dervish Bej, Tehhi Bej, Ahmet Dakli, Dako, Selman, Bllomshi, Gj. Qirias, Haxhi Bej dhe Irfan Bej, për të vajtur ndë Korçë që të zgjedhin Pleqësinë e Shoqërisë "Përparim” ("Bachkimi'i Kombit”nr. 1/1909). Sipas gazetës "Korça” nr. 24/ 1909, kryetar i Pleqësisë së Mësojtoreve Shqip u zgjodh Orhan bej Pojani. Për realizimin e detyrave aq të rëndësishme të saj, shoqëria "Përparim" u angazhua në forma e fusha të ndryshme.

Shtypi pasqyroi hap pas hapi, ndër të tjera, edhe veprimtarinë e Pleqësisë Kujdestare (Komisionit të Shkollës), i përbërë nga: Ahmet Dakli, Emin Haxhi Ademi, Hysejn Ceka, Taqi Buda, Lef Nosi, Dhimitri Papa Kristo, Petre Dot Biba, kryesuar nga "patrioti dhe trimi i paepur Dervish Hima". Komisioni dërgoi "telegrafe kudo ndë Shqipëri për të kërkuar ndihmë për këtë qëllim..." (Po aty). Gazeta e "Shqypeja e Shqypënis" nr. 7/1909, qysh në gusht të atij viti, bënte thirrje patriotike "Trimënia e kombit shqyptar tani ka me u njoh për trimëni, me themelimin e mësonjëtorevet kombëtare, për të cilat, sicili shqypëtar, lypën t’mos ndryne zembrën dhe të ngurëtohet, po të xgjidhnë kuletën dhe të apë pa kursim për këta shejtore, në të cilat të na shëndriten fëmija në gjuhet vet, si gjithë kombet e qytetënuet." Duke iu referuar nevojave të Shkollës Normale të Elbasanit, gazeta "Korça” nr. 15/1910, qortoi dhe apeloi njëkohësisht: "Mjaft, pra o atdhetarë që u mentuat si jinni mentuar gjer tani, dyke përdorur pasjen tuaj për gjëra që sjanë të nevojshme dhe humbasin me jetën tuaj, bëheni emrin të vet të pavdekur dyke i ndihmuar kombit tuaj të dalë nga padija." Apele të tilla dhe ftesa për të ndihmuar Normalen e Elbasanit bëjnë edhe gazetat e tjera jashtë dhe brenda viseve shqiptare. Pasojnë edhe kontributet konkrete financiare, për çka dëshmojnë edhe listat e emrave të pjesëtarëve të klubeve 
dhe shoqërive të ndryshme (Amerikë, Amerikë Latine, Bukuresht, Egjipt, Stamboll etj), të cilat prezantoheshin në vijimësi në gazetat e asaj kohe. Sa për liustrim po theksojmë njoftimin e gazetës "Korça" nr. 25/1909, ku thuhet: "Në Sallahorë u formua një shoqëri shqiptare për të ndihmuar Shkollën Normale. Anëtarët e kësaj shoqërie paguajnë 2 për qind nga rrogat e tyre për muaj." Edhe në një njoftim tjetër të gazetës "Flamuri” nr. 1/1910, lexojmë: "I nderçim kryetar i Shoqënisë 'Besa-Besë'Z. Kristo Kirka. Të gjithë Shqiptarët e këtushmë në Canton, Oh, për të çfaqur dashuri' e atdheut edhe për dritën e kombit shqipëtar me gjithë zemër-dashjen po dhurojmë ca të pakta për Shkollën Normale t'Elbasanit. Ju lutemi të radhosni emërat e ndihmëtarëve në gazetë."

Aktivitet i gjerë për grumbullimin e mjeteve financiare për Normalen e Elbasanit u zhvillua edhe brenda vendit. Kështu p.sh. gazeta "Bashkimi" nr.10/1910, njoftonte se në Shkodër u formua "Komisioni i t'mbledhunave per Shoqëni Perparim” me anëtarë: Kol Kraja, Mark Hila, Gjon Bumçi, Kol Kodheli, Pjetër Troshani dhe Kel Marubi.

Shtypi shkruan me admirim edhe për ndihmën e pakursyer të individëve të veçantë, ndër të cilët u shqua sidomos Hasan Prishtina, i cili ishte në krye të një komisioni për ndihmë të Shkollës Normale. Nuk ka gazetë të asaj kohe që nuk shkroi për aktet patriotike dhe kontributin e tij për Shkollën Normale. Për atë, ndër të tjera, thuhet: "prishën shumë të holla pa kursim, tuj mos ju dhimb as’pak." (“Shqypeja e Shqypënis”nr. 16/1910); “mblodhi një ndihmë të mirë për përparimin e kombit tonë." ("Bachkim’i Kombit" nr. 29/1910). Përmes gazetës turke "Ikdam" këshillonte të gjithë të pasurit shqiptarë që të jepnin një pjesë nga të ardhurat e tyre për përparimin e shkollave në Shqipëri. ("Bchkim'i Kombit”nr. 15/1909). Nëpërmjet gazetës turke "Sabah", ai kërkonte që patriotët shqiptarë të Anadollit, të dhjetën ose të njëzetën pjesë të rrogës së tyre t’ia dërgonin shoqërisë "Përparim" (Korçë). Shembull për këtë ishte vetë Hasan Prishtina. Me shpenzimet e veta i mbajti disa nxënës në Normalen e Elbasanit ("Bachkim'i Kombit" nr.7/1909), u bleu nxënësve veshëmbathje etj. Gazeta "Tomorri” nr. 2/1910, njofton: "Hasan be' Prishtina kishte dërguar dymbëdhetë herorë (sahate): katrë me mbulesë t’artë dhe tetë me rreth të këtillë...” Ato ua dhuroi nxënësve më të mirë të Normales. Për shkak të aktivitetit të tij patriotik, sjelljes së nxënësve kosovarë në Normalen e Elbasanit, ndihmave materiale, organizative etj., shtypi patrotik i asaj kohe, Hasan Prishtinës, i rezervoi epitetet më të larta, si: "i nderëshmi", "i çkëlqyeri”, "deputeti shqiptar", "i flakti atdhetar", "i çquari mëmëdhetar", "zotënia i flagët", "shumë i vlyeti atëdhetar i flagët", "atdhetari i ndiet", "i çkëlqyeri atdhetar edhe luftëtar", "engjulli” etj. Në 


\section{Albanon}

\section{Revistë kulturore}

gazetën "Shqypeja e Shqypënis" nr. 16/1910, lexojmë: "Linden shum e ma shum, si zotënia i flagët, Hasan bej Prishtina, i cili me vllazënit e ti, bijt e flagët të Shqypënis, cilët e kan ngrit shum nalt flamurin e Amës Shqypëni dhe u kan hedh si dragoj në flagët e luftës rrepët kundra padijes, për shëndritjen e kombit Shqypëtar dhe rrojtjen e Shqypënis."

Shtypi njoftonte edhe për kontributin e shumë nëpunësve shqiptarë në administratën osmane, të cilën dëshironin të mbeteshin anonimë për shkak të pasojave nga pushteti osman.

Komisioni i Shkollës Normale "mori me qira shtëpin' e Hysen Bezylfit, ku do të bëhen mësimet gjer sa të bëhen ndërtesat' e veta." ("Bachkim’i Kombit”nr. 5/1909). Kjo zgjidhje vlerësohet e përkohshme, deri sa Komisoni të sigurojë një ndërtesë të mirë, me sipërfaqe të gjerë, “e qi ti përgjigjet jo vetëm dinjitetit të këti kombit tonë madhështuer e të vjetër, por edhe zellit dhe vullnetit të nxënësvet, edhe shpresës së madhe qi ka varun mbi të gjithë kombi ynë." ("Bachkim'i Kombit"nr. 32/1910).

Pedagogët e Normales së Elbasanit. Përzgjedhja e stafit pedagogjik të Normales ishte një çështje shumë e rëndësishme, e cila u trajtua qysh në Kongresin Elbasanit. U bënë përpjekje për sjelljen e kuadrit më të kualifikuar, më të ditur si nga jashtë, ashtu edhe nga brenda vendit. Personaliteti dhe sjellja e tyre përcillej me vemendje nga shtypi i kohës. Një shkodran asokohe do të shkruante: "na shqyptarëtë me haree t’madhe po shofim sot tç̧ilun nji shkollë Normale, ku janë thirrë me msue shqyptarët ma t'diëshmit e ma t'atdhetartë qi Shqypënia nderohet m’i pas bes t'birit e vet; e nder këta msusa na, vendsit e k'tii gjyteti, e po kena ngushllimin t’posaçem me paa t'zgiedhun per dreituer nji shkodranë, emni i t'cilit asht $i$ njoftun n' Shqyptarii si per dije e si per pelqire tiera qi me dije bashkohen e prejë saj nuk munden m’u daa." ("Bashkimi" nr. 3/1910).

Arritja e pedagogëve të Normales së Elbasanit përcillej me admirim nga elbasanasit dhe pasqyrohej vazhdimisht në shtyp. Kështu gazeta "Bachkim' i Kombit" nr. 10/1909 njoftonte se "Javën që shkoj ardhë këtu edhe mësonjësit e tjerë që priteshin: z. Luigj Gurakuqi, i cili vate në Shkodër dhe Itali për të marrë plaçkat e veta dhe z. Alex Xhiovani." Po në këtë shkrim thuhej: "Shkolla Normale sivjet do të ketë si mësonjës z. L. Gurakuqin, Sotir Pecin, Alex Xhiovanin, një oxhë për të mësuarë djemtë fenë Myslymane dhe një të Krishterë për të mësuarë nxënësit fenë të Krishterë." Gazeta "Korça”nr. 24/1909 shton se "Me 17 të Vjeshtës III u zgjodh z. Dhimiter Paparistoja për me marrë mësimet e kangëvet e të gjimnastikës. Ai është njëri ndër mësuesit më të mirë dhe dashamirës i gjuhës shqipe. Për mësimet e fees orthodokse u zgjodh z. Peter Dotbiba." 
Një listë më të plotë të pedagogëve të Normales së Elbasanit, sipas lëndëve mësimore që kanë mbajtur ata, e gjejmë në gazetën “Tomorri” nr.11/1910, e sistemuar në këtë mënyrë:

Fe muhamedane mbante Hafiz Ibrahimi nga Tirana;

Fe të krishtërë-z. Peter Dotbina;

Gjuhësi - z.z. Luigj Gurakuqi, Aleksandër Xhuvani dhe Simon Shuteriqi;

Matematikë- z. z. Sotir Peci, Peter Dotbiba dhe Hasan Mezja;

Histori -z. z. Aleksandër Xhuvani dhe Hasan Mezja;

Shkenca- z. z. Sotir Peci dhe Luigj Gurakuqi;

Gjeografi - z. Peter Dotbiba; Logjistikë-Luigj Gurakuqi;

Bukurshkrim-Luigj Gurakuqi;

Vizatim -Luigj Gurakuqi;

Mësim gjanash (Leçons de choses) - z. Peter Dotbiba;

Turqisht - Hafëz Ibrahimi;

Frengjisht - Aleksandër Xhuvani;

Gjimnastikë- Dhimitër Papahristo;

Këngë - Dhimitër Papahristo.

Nxënësit e Normales /normalistët e parë në Shqipëri. Pas përpjekjeve dhe përgatitjeve të nevojshme (aq sa ishte e mundëshme), erdhi koha e njoftimit dhe e thirrjes së të rinjve (djemve) shqiptarë për t’u regjistruar në këtë "tempull të dijes kombëtare". Komisioni i shkollës, përmes shtypit, njofton: " $U$ bëjmë të njohur atdhetarëvet si dhe prindërvet, se dëshira e përgjithshme u mbush me ndihmen po thuaj e gjithë Shqipërisë, se Shkolla Normale hapi dyert për të shkrojtur nxënës me 24 të këtij muaji dhe me tre të muajit që vjen do të nisin mësimet..." (Bachkim'i Kombit, nr. 6/1909). Komisioni që në fillim u kujdes për strehimin e nxënësve që do të vinin nga viset e tjera jashtë Elbasanit, siç dëshmon edhe ky njoftim në shtyp: "Për të lehtësuar rojtjen e nxënësvet dhe për të qetësuar prindet komisioni i shkollës hapi një shtëpi dhe mer përsipër me një pagesë 10 lira turq (të cilat do të paguhen me dy kohëra), ushqimin dhe të ndenjurit. Nxënësit janë të detyruar të kenë shtresat e nevojëshme dhe rrobat e trupit me rregull." (Po aty).

Filluan të paraqiten edhe nxënësit e parë, fillimisht nga Elbasani, siç dëshmon shtypi. Në një gazetë të kohës lexojmë: "Të martën zunë të shkruajnë djemtë. Mora vesh (thotë autori) se 25 djem duallë nga shkolla Idadije dhe u shkruan nëshkollën Normale" ("Bachkim’i Kombit”, nr. 10/1909).

"Me 26 fruur (shkruan gazeta "Bashkimi” nr. 10/1910) Filipi Iakë Biankut u nisnë prejë Shkodret për mësojtore t'Elbasanit” dhe vazhdon "Qietri si e 


\section{Albanon}

\section{Revistë kulturore}

dime asht Qiazim Perdoda qi shkoj Kshnedhash.” Po këtu kërkohej nga paria e Shkodrës që në Normalen e Elbasanit të dërgonin edhe nxënës të tjerë shkodranë.

Vëmendje e veçantë i kushtohej nxënësve nga Kosova. Sipas gazetës "Liria" nr. 64/1909, në fund të vitit 1909, me ndihmën e Klubit Shqiptar të Shkupit, për në Normalen e Elbasanit, u nisën këta nxënës: Ali Riza, Mehmet Prishtina, Meçabi Shefik Shkupi, Junus Emin Ipeku, Muharem Ymer Velçetrini, Hamdi Ibrahim Jakova dhe Shaban Mitrovica. Në janar të vitit 1910, nga Kosova u nis edhe një grup tjetër nxënësish: Shyqri Malush nga Gilani, Qamil Zejnel nga Gilani, Nevzat Sherif nga Gilani, Mehmet Jusuf nga Velçetrini, Sylejman Bajram nga Velçetrini ("Liria” nr. 16/1910). Vazhdonin njoftimet edhe për nxënës të tjerë nga Kosova, Shkupi, Dibra etj., të nisur për në Elbasan. Gazetat njoftonin edhe për arritjen e nxënësve nga Kosova në Elbasan, si p.sh. gazeta "Bachkim’i Kombit” nr. 29/1910, nëpërmjet artikullit "Nxënësit nga Kosova për në Elbasan", njoftonte se " $M e$ 19 të këtij muaji (mars H. K.) ardhën këtu (në Manastir H. K.) 17 nxënës nga Kosova për shkollën Normale t’Elbasanit.” Ata ishin: Ali Riza nga Mitrovica, Safet nga Mitrovica, Muharem nga Mitrovica, Arsllan nga Jakova, Hajredin nga Jakova, Ramis nga Jakova, Haki Morina nga Jakova, Xhemal nga Ipeku, Ismajl Haki nga Shkupi, Reshat nga Prishtina, Riza nga Prishtina, Vehbi nga Prishtina, Xhemil nga Prishtina, Hasan nga Vuçiterni, Qazim nga Vuçiterni, Emin nga Vuçiterni dhe Ilias nga Vuçiterni. Në fund, artikullshkruesi nxënësve kosovarë u dëshironte sukses dhe jetë të gjatë. Gazetat shënojnë edhe pritjen e ngrohtë dhe vëllazërore të nxënësve kosovarë nga elbasanasit. Në shkrimin "Pritja e nantëmëdhetë nxanësve për në Shkollën Normale", gazeta "Tomorri” nr.3/1910, ndër të tjera paraqet edhe listen e djemve nga Kosova, të arritur në Elbasan më 25 mars 1910: Safet Rustemi nga Gjakova, Arsllan i Mehmet Currit nga Gjakova, Hajredin i Hasan Kumanovës nga Gjakova, Muharremi i Bajram Lushdës nga Gjakova, Ismajl Haki i Morinës nga Gjakova, Remsi i Ibrahim Agës nga Gjakova, Rashit Arifi nga Prishtina, Xhemajli i Jahja Begut nga Prishtina, Vehbi Ibrahimi nga Prishtina, Riza Ragipi nga Prishtina, Qazim Mustafa nga Vuçitërni, Emin’i Dibran Kastratit nga Vuçitërni, Ilias Hasani nga Vuçitërni, Hasan Abedini nga Vuçitërni, Ali Riza i Mustafa Berishës nga Mitrovica, Xhemali Abdurrahimi nga Ipeku, Ibrahim Kadria nga Berisha, Tekki Mustafa nga Struga, Osman Zymberi nga Struga, Maliqi i Selim Dacit nga Dibra. Gazeta “Tomorri” nr.3/1910, në faqen e parë të saj shkruante: "Te Enjten më 25 të muajit që jemi (mars H. K.) nxanësit e Shkollës Normale bashkë me profesorët e tyne, me qeleshet 
e-bardha përmbi krye, kishin dalunë me kohë për jashta qytetit për me pritun nantëmëdhetë djem që po vishin prej Kosove dhe prej Struge." Shtypi shkruante për kontributin e madh të Hasan Prishtinës, Nexhib Dragës etj., për sjelljen e këtyre nxënësve në Elbasan.

Gazeta "Tomorri" nr. 1/1910, theksonte se Normalja po përparonte dhe se për tre muaj e gjysmë ishin mbledhur më shumë se 100 nxënës nga të gjitha krahinat shqiptare. Në gazetën "Tomorri” nr. 11/1910, paraqitej lista e qyteteve dhe numri nxënësve në Normalen e Elbasanit (ndonëse jo e plotë siç thotë vetë autori): Nga Elbasani-50 nxënës, Tirana-4, Berati -1, Peqini -1, Shpati -6, Gjirokastra-2, Peja-1, Gjakova-3, Mitrovica-3, Prizreni-2, Shkupi-4, Delvina-1, Picari-1, Përmeti-3, Libohova-3, Struga-1, Dibra-7, Starova-2, Shkodra-2, Kruja-1, Kavaja-1, Gilani-5, Vuçitërna-5, Presheva-2. Këtë e konfirmon edhe Aleksandër Xhuvani në kujtimet e tij, kur thotë: "U mblodhën nxanës nga gjithë viset e Shqipnisë, që kishin ndjekë shkolla fillore ose të mesme të ndryshme, në gjuhën turqishte e greqishte." ("Normalisti" numër përkujtimor 1909-1959).

Në fjalimin e tij, në ceremoninë e provimeve publike, Luigj Gurakuqi, ndër të tjera, do të deklaronte: "Shqypënia u lëkunt e tanë nga zani i Shkollës Normale; atdhetarët shqyptarë, që prej sa kohe kishin nji etje të madhe për mësim e për ditunië, nuk $i$ kursyen ndihmat e veta të begata, e djemt t’onë rrodhën nga të gjitha viset e Shqypëniës e u-derdhën këtu n'Ebasan,... E jo vetëm nga Toskëria, që ka qenë gjithmonë e para ndë tregimet kombëtare e ndë luftat e gjuhës, po ma fort nga Gegënia e sypërme, nga ajo Kosova fisnike e trimoshe, me të përpjekunit e të nderëshmit Hasan be Prishtina, i cili na rroftë për jetë, na erdhën mjaft nxanës, sa që mund të thohet, pa frikë lajthimi, se nuk kaa kant të Shqypëniës, që mos të ketë këtu mbrenda përfaqësonjësin e tij...” (“Liria” nr. 94/1910).

\section{Fillkremtimi i Shkollës Normale dhe veprimtaria e saj gjatë vitit të parë} shkollor (shtatëmujor). Nga shtypi i kohës mësojmë se "fillkremtimi" (inaugurimi) i Normales u bë më 18 nëntor 1909. Gazeta "Korça” nr.24/1909 shkruante: "Me 18 të Vjeshtës III njerzia e Elbasanit gjindej në një lëvizje, shkaku i së cilës ishte fillkremtimi i shkollës Normale...Qyshë në orën katër të mëngjesit shkolla dhe oborri i saj për rreth ishin të mbushur plot njerëz." Ndërsa gazeta "Bachkim'i Kombit” nr. 13/1909 shkruante: “Ndë këtë festë kombëtare muarnë anë tërë populli i Elbasanit.” Në këtë ngjarje të madhe morën pjesë edhe personalitete të larta dhe atdhetarë të shquar, si Mytesarifi Aqif Pasha, pastaj patrioti Dervish begu (Dervish Hima), Shefqet begu etj., misionari amerikan, përfaqësues të klubit "Bashkimi” të Elbasanit, nxënës, pedagogë të shkollës në krye me Luigj Gurakuqin etj. ("Korça”, nr. 24/1909). 


\section{Albanon}

\section{Revistë kulturore}

Inaugurimi (fillkremtimi) i Normales filloi në orën pesë të mëngjesit (“Baschkim’i Kombit" nr. 13/1909). Filloi me fjalën përshëndetëse të përfaqësuesit të klubit "Bashkimi”, në gjuhën turqishte (Po aty). Në këtë atmosferë festive e madhështore fjalën e mori "atdhetari i palodhur dhe i ditur, drejtori i Shkollës Normale, Luigj Gurakuqi”, i cili mes tjerash, tha:

"Dita e sotme, kjo ditë e bardhë e plot hare, që gdhini sot mbi qytetin tonë, do të mbetet si nji ditë e madhe si nji ditë e shqueme e e paharrueshme në histori të kombit tonë; do të qëndrojë si nji kremte e shejtë e e përjetëshme, e cila do të lutet me nderim e me brohoritë, babë mbas babe e djal mbas djali, ndër kohnat e panumërueshme që do të vijnë e deri në jetë të jetës.

Kombi shqyptaar, që shkëlqen gjithmonëpërmbi t’tjerët me trimëniën e fisnikniën e vet; ky komb që përmendet kudo, e me nderë e me lavdim prej të gjithëve, për besën e burrëniën, që kurr sï ka mohuar, ky komb po i shton vetvetes edhe nji tjetrë vetië të mirë, dua të them dashuniën për mësimin e për dituniën qü e kishte gjithënjë në gjak e në natyrë, po që mjerisht nga shumë e shumë shkake nuk mundi deri më sot t'a rëfente e t'a zhvillonte ashtu si duhej. ("Normalisti", numër përkujtimor 1909-1959).

Veprimtarinë e vet arsimore Normalja e Elbasanit e filloi në kushte shumë të vështira dhe me mungesa elementare, siç ishin edhe tekstet shkollore, të cilat pasqyrohen edhe në shtypin e kohës. Në gazetën "Tomorri” nr. 1/1910, lexojmë: "Nga mungesa e libravet (pedagogët e Normales, H. K.) shtrëngohen të përmbledhin andej e këndej, porsi ajo mbleta punëtore mjaltën ésaj nëpër lulet, të-përkthejnë mësimet e-nevojëshme dhe ma së fundi të krijojnë edhe vetë me një gjuhë të-bukurë dhe t'amblë, me një gjuhë po thua të-përbashkme qi kuptohet lehtësisht si prej Toskëve si prej Gegëve." Për sigurimin e teksteve mësimore dhe të literaturës tjetër të nevojshme, jo vetëm për mësimin në Normale, por edhe më gjerë, u angazhua Komisioni i Shkollës, sidomos kryetari i saj, Dervish Hima. Në emër të Komisionit, ai thekson nevojën e madhe për një bibliotekë “të pasur nga e cila do të mundin mbledhën lëndën e nevojshme për mësim profesorët; u-lutemi të gjithë atdhetarëvet të vërtetë të ndihmojnë mbëledhje librash... në çdo gjuhë a subxhekt që të jenë." ("Rrufeja” nr.12/1909). Jep udhëzime edhe për mënyrën se si do të dërgoheshin këto libra në destinacionin e tyre. Dervish Hima konsideronte se biblioteka e Normales së Elbasanit do të ishte filli (bërthama) e një biblioteke kombëtare shqiptare.

Përkitazi me fillimin e mësimit, duke përfshirë edhe tekstet mësimore, Aleksandër Xhuvani, drejtori shumëvjeçar i Normales, kujtonte: “mësimet, si ua shpjegojshim nxënësvet, ua jipshim me të shkrueme, në dispensa: i shkruejshim 
pra mësimet së pari me dorë, mbasandaj letrën e shkrueme e shtrijshim përmbi nji dërrasë pak të fellë katërkëndëshe, të ndërueme për këtë qëllim, së cilës $i$ shtihej mbrenda nji farë lande e bardhë si pelte,... Shkrihej kjo landë në zjarr dhe shtrihej n'ato dërrasa, ku ngrinte mbas nji cope here; prej shkrimit qü ngulitej aty nga letra e shkrueme nxirreshin nga 50 e 60 kopje për çdo mësim. Në këtë mënyrë primitive kemi mbarue punën e gjithë landëvet të mësimit." (“Normalisti”, numër përkujtimor 1909-1959).

Sa i kushtohej rëndësi parësore teksteve shkollore shqipe në atë kohë dëshmon edhe fakti se shoqëria "Përparimi” në Korçë zgjodhi një komision të veçantë "për të kritikuar librat shkollore që do të shkruhen paskëtaj, i përbërë nga "E çkëlqyera atdhetare Zonjëza Sevasti Qirias, Z. Z. Gligor Cilka, Thanas Floqi, Hafez Ali, Thoma Abram, Dionis Themel, Sami Pojani, Nikolla Zoi, Bedri Effendi, Dimitri Berati dhe Hil Mosi" ("Flamuri"nr.2/1910).

Krahas teksteve mësimore, mësimdhënësit e Normales dhe veprimtarët e tjerë punuan shumë për sigurimin e mjeteve të tjera mësimore, për metoda të reja, për shndërrimin e saj në një qendër dinjitoze të arsimit profesionalpedagogjik, të edukimit patriotik dhe humanist të rinisë shqiptare. Model për këtë ishin vetë mësimdhënësit. Mirënjohje të thellë ndaj sjelljes dhe punës së mësimdhënësve dhe popullit të Elbasanit në tërësi shprehu tërë opinioni patriotik shqiptar, duke përfshirë edhe nxënësit nga Kosova. Sipas gazetës "Tomorri" nr. 13/1910, disa prej tyre deklaruan se "atë që na kanë bërë profesorët, kujdestarët e gjithë njerëzija n'Elbasan s’ na i kanë bërë kurrë prindërit tonë."

Erdhi dita e shumëpritur, dita e 23 qershorit 1910, dita e provimeve vjetore publike. Ishte një ditë festive dhe shumë e rëndësishme për Shkollën Normale, për mësimdhënësit dhe nxënësit e saj. Ishte dita kur normalistët do të testonin dijet e tyre në mënyrë publike, në praninë e mësimdhënësve, të drejtorit të shkollës, të autoriteteve civile, ushtarake e policore të qytetit, të prindërve të nxënësve dhe të qytetarëve të tjerë elbasanas. Ngjarje e jashtëzakonshme: provimet vjetore publike.

Ceremonialin e provimeve e hapi drejtori i shkollës, Luigj Gurakuqi. Sipas gazetës "Liria" nr. 94/1910, Luigj Gurakuqi, ndër të tjera tha:

"Shtatë muaj ma parë, n’atë ditë fatbardhe e të paharrueshme, në të cilën u hapën dyert e kësaj Shkolle Normale e u vërtetuan kështu shpresat e ushqyeme prej sa e sa vjetësh në mest të brengëvet e të pësimevet, e u-mbushën me 'të dëshirat e flakta të zembravet shqyptare, u mundova të çquanja e të kufisonja mirë përpara zotëriës s’uajë nevojën e madhe që kaa kombi ynë për mësim e ditunië, e të ju dëshmonja e të 


\section{Albanon}

\section{Revistë kulturore}

ju rrëfenja ndë pak fjalë se, për t’arrimun ma shpejt qëllimin tonë e për t’a bamun mësimin ma të lehtë e ma të fitimshëm, lypsej që mësimi të ipej në gjuhën e mëmës.

Sot që kemi nderin të ju shohim përsëri të mbledhunë në këtë vënd të bekuarë, në këtë çerdhe të dituriës shqyptare, shpresojmë se nuk do të ju mbaj ma vetëm me fjalë të gjata e të thata, po do të mundohemi të ju vërtetojmë, me vepra e me tregime, mendimet $e$ fjalët tona e të ju japim një provë të vogël po të kthjelltë të dobiës e të frytit që sjell ky lloj mësimi tue ju shtrumun përpara pemët e reja të kësaj vjete shkollore..."

Pas fjalimit të zjarrtë të Luigj Gurakuqit, filloi programi i ceremonisë së provimeve publike (i shkruar në gjuhën shqipe dhe turqishte), i cili përmbante: Dua (lutje fetare, H. K.), Kangë Mbretit, Ligjëratë Shqype, Ligjëratë Turqishte, Fe (mësim fetar, H. K.), Kangë, Gjuhë Shqype, Shkenca, Historië, Arithmetikë, Vjershë Shqype, Shkenca, Kangë, Gjuhë Turqishte, Gjeografië, Gjeometrië, Gjuhë Frangishte, Logjistikë, Darja e çmimeve, Kangë, Gymnastikë (“Tomorri” nr. 12/1910). Shtypi dëshmon se provimet dhe dijet e nxënësve e shkathtësitë e tyre në gjuhën shqipe, shkenca etj. i gëzuan dhe mallëngjyen të pranishmit. Rezultatet e nxënësve të saj dëshmuan një epërsi të lartë ndaj mësimit në shkollën turke, gjë që nxiti gëzimin dhe krenarinë e shqiptarëve të pranishëm. Kështu, Normalja e Elbasanit, përkundër shumë pengesave e vështirësive, vitin e parë shkollor e përmbylli me sukses të jashtëzakonshëm.

Nëpërmjet citimeve të përzgjedhura nga shtypi i kohës, të shfrytëzuara në këtë shkrim, u përpoqa që për lexuesit e sotëm, të sjell në mënyrë sa më origjinale fragmente pune dhe atmosfere nga themelimi dhe fillimi i misionit të saj. Emri i mirë (madje, $i$ shenjtë) $i$ Normales së Elbasanit, vlerat $e$ padiskutueshme arsimore-pedagogjike e shkencore të saj, të kultivuara në vite, dubet të ruben me respekt, me dashuri, por edhe me fanatizëm racional, në radhë të parë, për ne dhe për brezat që do vijnë. Shumë universitete në botë e shkolla të tjera $u$ themeluan shekuj më parë, por ato janë krenaria e vendeve dhe kombeve respektive edhe aktualisht. 